Khawarij Milinial: Transformasi Khawarij Dari Masa........

\title{
KHAWARIJ MILENIAL: TRANSFORMASI KHAWARIJ DARI MASA LAMPAU MENUJU MASA SEKARANG
}

\author{
Oleh: \\ Ahmad Sudi Pratikno \\ Program Studi PGMI, Institut Agama Islam Al-Falah As-Sunniyah, Kencong, Jember \\ ahmadsudi.ibnsuman@gmail.com
}

\begin{abstract}
As a multicultural country, Indonesia should be able to fortify its young generation, for not exposed to radicalism and extreme understanding. The doctrine of khawarij, this doctrine triggered the emergence of new radical groups that spread throughout the world. The content analysis has been done, and was found that the propaganda of the millennial khawārij still occurs until right now. This certainly becomes a preventive and anticipative actions should be taken from the government and the societies. In addition, with the bonus demography that has been taken place in Indonesia, these opportunities should be maximized for the benefit of the country, nation, and religion as well as maintaining the integrity of the Indonesian country.
\end{abstract}

Keywords: khawārij, past time, future time

\begin{abstract}
ABSTRAK
Sebagai negara yang majemuk, Indonesia harus mampu untuk membina generasi muda agar tidak terpapar radikalisme dan faham ekstrim. Doktrin khawārij memicu munculnya kelompok-kelompok radikal baru yang tersebar di seluruh dunia. Analisis konten yang telah dilakukan, ditemukan bahwa propaganda oleh kaum khawarij milenial masih terjadi hingga saat ini. Hal tersebut harus dilakukan tindakan pencegahan dan antisipasi dari pemerintah maupun masyarakat. Selain itu, dengan bonus demografi yang terjadi di Indonesia, kesempatan tersebut harus dimaksimalkan untuk memberikan manfaat bagi negara, bangsa, dan agama serta menjaga keutuhan negara Indonesia.
\end{abstract}

Kata Kunci: khawārij, masa lampau, masa sekarang

\section{Pendahuluan}

Khawārij yang menjadi salah satu aliran dalam Islam mengalami sejarah perkembangan yang cukup panjang, mengingat awal mula munculnya golongan ini ada di masa kekhalifahan. Bahkan, benih-benih kemunculan khawārij telah tampak pada zaman Rosululloh S.A.W. Aliran ini muncul dan meresahkan dunia disebabkan propaganda ideologi mereka yang tergolong ekstrim dan radikal. Pada zaman kekhalifahan Ali bin Abi Tholib R.A., khawārij berkembang menjadi kuat dan berdigdaya. Salah satu bukti nyata adalah peristiwa yang menimpa sahabat Ali bin Abi Tholib R.A. yang dipanah tepat dibagian jantung pada saat sholat shubuh berjamaah. Pemanah tersebut tidak lain adalah Abdurrahman bin Muljam, salah satu anggota khawarij yang hafal alquran 1 .

${ }^{1}$ NU Online, Ibnu Muljam Membunub Ali karena Hoaks http://www.nu.or.id/ post/read/91475/ibnu-muljammembunuh-ali-karena-berita-hoaks

30 | Jurnal Auladuna

Vol.미. No.D2. April 2019 
Pada perkembangannya, banyak kalangan memprediksi kaum khawārij sudah tidak ada lagi, namun khawārij meninggalkan prototype yang menjadi cikal bakal munculnya gerakan ekstrimis di kalangan umat Islam. Prototype ini juga menjadi basis dan pondasi dalam melancarkan doktrin radikal kepada umat Islam. Meskipun hanya mewarisi pemikiran radikal, namun dampaknya sangat berbahaya bagi umat Islam tentunya. Doktrin radikal ini secara perlahan memunculkan gerakan-gerakan ekstrimis baru seperti wahabi, al-qaeda, hizbut tahrir, JI, dan ISIS.

Seiring dengan perubahan zaman, pola pergerakan khawārij juga berubah dan bergeser dari cara konvensional menuju cara yang lebih modern dan praktis. Cara yang lebih modern dan praktis ini dapat ditelusuri melalui penggunaan media sosial seperti WhatsApp, Twitter, dan Facebook dengan melacak akun-akun ekstrimis dan mengetikkan kata kunci yang erat kaitannya dengan radikalisme. Khawārij milenial memanfaatkan media sosial untuk menebar kebencian, memojokkan salah satu golongan yang berbeda haluan bahkan menyerang dan memusuhinya, serta me-takfir-kan orang lain yang tidak segolongan. Fakta di lapangan ditemukan banyak sekali kasus yang termasuk ke dalam ekspansi doktrin yang masif oleh kaum khawārij milenial terhadap pengguna media sosial. Tidak berhenti disitu, dalam konteks kekinian khawarij milenial juga menyerang orang yang berbeda pandangan politik. Caci maki, hujatan, bahkan hinaan dapat dengan mudah kita temukan di media sosial, apalagi pada tahun politik seperti saat ini. Meskipun pemerintah telah menyusun dan mengesahkan UU ITE yang didalamnya mengatur segala perilaku elektronik para netizen, tentu tidak semua aktivitas tersebut dapat terlacak dan dianalisis satu per satu. Banyaknya akun-akun ekstrimis dan berita hoax membuat pakar ITE dan aparat penegak hukum harus bekerja ekstra untuk meminimalisir bahkan menekan angka propaganda kaum khawārij di media sosial.

Fenomena ujaran kebencian, penyebaran hoax, dan propaganda lain yang sering ditemui di media sosial adalah fenomena gunung es dimana kemunculan peristiwa-peristiwa tersebut hanyalah segelintir dari banyaknya kasus-kasus propaganda lainnya yang tidak terekspos di khalayak umum. Media cetak maupun elektronik hanya membuat beberapa headline berita yang tentunya sebagai bahan untuk dilihat dan diperbincangkan oleh masyarakat umum, padahal peristiwa semacam ini masih banyak yang belum ditayangkan oleh media.

Oleh sebab itu, penting bagi pegiat media sosial untuk memahami pola pergerakan kaum khawārij milenial di media sosial serta dapat memilih dan memilah, menyeleksi, menebarkan informasi dan kabar yang valid sehingga propaganda dan penyebaran berita hoax di kalangan masyarakat dapat ditekan secara maksimal. Menjadi pengguna media sosial yang santun dan mencerahkan jauh lebih elegan daripada menyebarkan berita yang tidak penting dan memicu perpecahan bangsa. Seperti hadits nabi muhammad SAW yang artinya "bicaralah yang baik, jika engkau tidak mampu maka diamlah"2.

\section{Pembahasan}

\section{Peyorasi Kata "Radikalisme"}

Sebelum membahas lebih jauh tentang kaum khawārij, sudah seyogyayanya kita membahas tentang kata radikalisme yang menjadi pola pergerakan, doktrin, dan prototype dari kaum khawārij. Secara bahasa, radikalisme berasal dari dua suku kata, yakni "radikal" dan "isme". Kata "radikal" berasal dari kata "radik" yang berarti akar, sedangkan "isme" berarti paham atau aliran pemikiran. Secara gramatikal, kata radikalisme berarti suatu paham atau aliran pemikiran yang telah mengakar dan tertanam kuat dalam pikiran seseorang. Akan tetapi, makna kata "radikalisme" telah melenceng jauh dari makna leksikalnya. Bahkan kata

${ }^{2}$ NU Online, www.nu.or.id/post/read/72224/berkatalah-yang-baik-atau-diam-saja

Vol.I. No.D2. April 2019 
"radikalisme" telah disandarkan dan identik dengan kekerasan dan propaganda perang. Padahal jika radikalisme dapat dimaknai secara bijak, maka paham ini dapat diisi dengan kebaikan dan mengajak kepada kerukunan, kebersamaan, dan ketentraman hidup.

Perlunya klarifikasi publik dan pemurnian kata tentang arti sebenarnya radikalisme, walaupun memang kata "radikalisme" telah tersebar luas di masyarakat dan melekat dalam pemikiran masyarakat, sehingga akan sulit untuk diubah. Salah satu langkah solutif adalah dengan menggerakkan Badan Pengembangan dan Pembinaan Bahasa Indonesia untuk meluruskan dan meredefinisikan arti kata radikalisme. Untuk selanjutnya dapat dilakukan promosi kepada masyarakat dalam bentuk buku, pamflet, maupun postingan di media sosial.

\section{Sejarah Perkembangan Khawārij}

Pada beberapa literatur, khawārij diartikan sebagai sekelompok orang yang memiliki pemikiran sendiri serta cenderung menyimpang dari kebanyakan masyarakat umum. Khawārij adalah bentuk jamak dari Kharijis/Kharijah/Kharijities. Kharijis/Kharijah/ Kharijities merupakan kelompok awal sektarian islam dan menjadi pembebas ${ }^{3}$. Khawārij juga berasal dari kata kharaja yang berarti keluar. Kelompok ini mendukung Sayidina Ali sebagai pemimpin karena kebijaksanaan dan kealiman beliau ${ }^{4}$. Selain itu, khawarij merupakan kelompok sektarian ketiga terbesar dalam agama Islam. Namun, khawārij bukan bagian dari sunni maupun syiah. Khawārij datang sebagai bentuk eksistensi dari fitnah yang besar pada tahun 656 dan $661 \mathrm{M}^{5}$. Mereka kemudian memutuskan untuk melawan Sayidina Ali R.A. pada saat terjadinya persekongkolan dengan Muawiyah. Puncaknya adalah kematian Sayyidina Ali R.A. yang meninggal pada tahun $661 \mathrm{M}$ di masjid Kufa karena tusukan pedang oleh kaum khawārij. ${ }^{6}$

Beberapa ulama mendefinisikan khawārij sebagai kelompok ekstrimis dan menentang. Muhammad ibn 'Abdul al-Karim al-Syahrastāan, berpendapat bahwa khawārij merupakan kelompok masyarakat yang memberontak dan tidak mengakui keabsahan imam 4, maupun imam-imam (pemimpin) yang hidup pada masa kekhalifahan dan pada masa tabi'in ${ }^{7}$. Imam alNawawi menyatakan bahwa khawarij adalah kelompok ahli bid'ah yang menghukumi orang yang melakukan dosa besar berarti kafir dan kekal di neraka. Bahkan mereka tidak mau menghadiri sholat jumat dan sholat berjamaah ${ }^{8}$. Sedangkan Ibnu Hajar Asqalani berpendapat bahwa kaum khawārij adalah para ahli bid'ah yang keluar dari Islam dan membelot dari pemimpin kaum muslimin?.

Pada perkembangannya, kaum khawārij keluar dari aqidah islam moderat dan menentang Sayyidina Ali R.A., Muawiyah, dan Bani Umayah. Kaum khawārij mulai berkembang dari masa ke masa. Pada abad ke 18 di Semenanjung Arab, muncul kelompok yang segaris dengan kaum khawarij yang dijuluki dengan kelompok Wahabi. Wahabi adalah para pengikut gerakan purifikasi (pemurnian) ajaran agama Islam ${ }^{10}$. Pendiri kelompok Wahabi adalah Muhammad bin Abd al-Wahhāb yang merupakan seorang ulama dari bangsa Arab. Muhammad bin Abd al-

\footnotetext{
${ }^{3}$ Zubaidah, S., dan M., Zulkifli, Doctrine and thought of khawarij and the implication in the present context, International Journal of Applied Engineering research, Vol. 11(6), 2016.

${ }^{4}$ The Oxford Dictionary of Islam

${ }^{5}$ John Alden Williams dan Justin Corfield. The Oxford Encyclopedia of Islamic World (Oxford Islamic Studies Online, 2019).

${ }^{6}$ Ibid.

${ }^{7}$ Muhammad ibn 'Abdul al-Karim al-Shahrastāan, al-Milāl wa al-Nihāl (Beirut: Dār al-Ma'rifah, 2000), hlm. 114.

${ }^{8}$ Muhyi al-Din Yahya ibn Syaraf al-Nawawi, Sharhu al-Nawāwi 'alā Sḥahih Muslim (Beirut: Dār Ihya al-Turāats, 1392 H.), hlm. 10:52.

9 Ibnu Hājar Ahmād ibn 'Ali al-Asqālani, Hadyu al-Sari: Muqoddima Fath Bāri (Beirut: Dār al-Ma'rifah), hlm. 283.

10 Tim Forum Kajian Ilmiah Ma’had Aly Lirboyo, Kritik Ideologi Radikal (Kediri: Lirboyo Press), hlm. 9.

32 | Jurnal Auladuna

Vol.DI. No.GZ. April 2019
} 
Wahhāb berpikir bahwa Islam pada zaman itu harus dimurnikan dari ajaran-ajaran sesat, teori rumit, dan ritual keagamaan yang dianggapnya melenceng jauh dari sunnah nabi. Maka banyak dilakukan penghancuran makam-makam sahabat rosul dan mujahidin.

Dampak dari penghancuran tersebut tentu akan menghilangkan warisan budaya islam yang semestinya harus dijaga dan dilestarikan. Kaum khawārij memiliki paham radikal dan tidak selaras dengan aqidah Ahlussunnah Wal Jama'ah. Radikalisme digunakan sebagai tumpuan untuk menggempur ideologi lain diluar ideologi yang mereka anut. Radikalisme memiliki sejarah panjang selama perkembangan Islam di masa lampau. Hampir seluruh peradaban islam pernah diterpa dengan masalah radikalisme.

Pergerakan khawārij tampak besar yang salah satunya berupa tindakan mengacaukan sebuah negara atas nama agama. Pergerakan inilah yang menjadi cikal bakal lahirnya terorisme di tanah air. Kelompok-kelompok seperti Jamaah Islamiyah, Hizbut Tahrir, dan Daulah Islamiyah adalah representasi doktrin dari prototype khawārij yang tekah muncul sejak zaman dahulu. Pada abad ke-19, Ikhwanul Muslimin muncul di tanah Mesir sebagai kelompok yang memiliki paham mirip dengan khawarij. Kelompok ini pada kenyataannya melahirkan aktivitas pemikiranpemikiran dan pergerakan yang menjadi penyebab utama aksi terorisme dan tokoh-tokohnya banyak menjadi pemimpin organisasi jihad lainnya.

Pada tahun 1952, Taqī al-Dīn al-Nabhāni mendirikan Hizbut Tahrir (HT) sebagai bentuk kekecewaan dirinya atas lunaknya Ikhwanul Muslimin dalam melakukan jihad membela agama ${ }^{11}$. Pada tahun 1960-an, Shāalih Sirriah mendirikan Jamaah Jihad yang bergerilya di tanah Mesir. Pendirian jamaah tersebut juga diikuti oleh Syukri Musthafā yang mendirikan Jamaah Muslimin atau yang sering dijuluki dengan Jamaah Takfir wal Hijrah karena seringnya mengkafirkan orang lain dan mewajibkan hijarh bagi pengikutnya ${ }^{12}$. Beberapa tahun kemudian terbentuk kelompok Al-Qaeda yang dipelopori oleh Usāmah bin Laden dan Aymān al-Zhawāhiri. AlQaeda memiliki basis di Afghanistan ${ }^{13}$.

11 Abdurrahman Wahid, dkk, Ilusi Negara Islam (Jakarta: The Wahid Institute, 2009), hlm.

86.

12 Ibid, hlm. 11

13 As'ad Said Ali, Al-Qaeda, hlm. 43.

Vol.DI. No.D2. April 2019 


\section{SKEMA IDEOLOGI ISLAM RADIKAL}

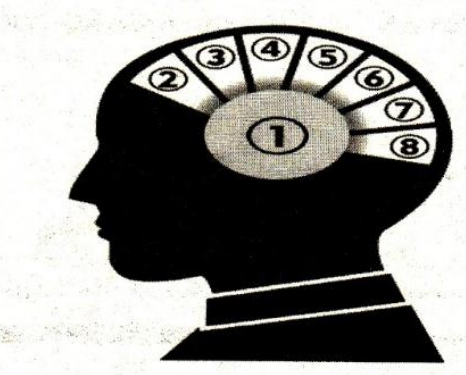

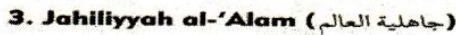
Keyakinan bahwa masyarakat telah mengalami fase Jahiliyyah seperti pada zaman Nabi.

5. Dar al-Harb atau Dar al-Kufri (دار المرب أر دار الكشفر )

Meyakini seluruh dunia ini adalah medan perang atau wilayah kufur.

7. Al-Amr bi al-Ma'ruf wa al-Nahi an al-Munkar

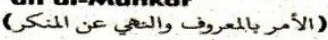

Upaya kekerasăn untuk melenyapkan segala kemungkaran.
1. Al-Hakimiyyah ( $a_{2} 5(1)$ )

-Paham Kedaulatan Allah-

Paham ini merupakan sumber dan pangkal ideologi Radikalisme.

2. Mengkafirkan Pemerintah dan

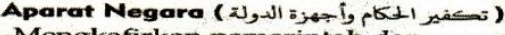
-Mengkafirkan pemerintah dan aparat negara-

Dari paham hakimiyyah tersebut, kemudian berlanjut pada vonis kafir terhadap pemerintah beserta aparat negara yang tidak menganut prinsip Al-Hakimiyyah.

4. Al-Wala" wa Al-Bara' (الولا: والبراء) Paham yang meyakini kelompoknya harus dibela dan dikasihsayangi, sedangkan kelompok lain harus dibenci, dimusuhi, bahkan diperangi.

6. Al-Jihad fi Sabilillah (الجبهاد في سبيل الش) Perjuangan menggulingkan dan melawan pemerintah serta aparat negaranya. Dan aksi pembunuhan terhadap orang-orang musyrik yang berbeda agama.

8. Iqamah al-Khilafah 'ala Minhaj


Agenda besar, cita-cita politik dan final dari segala perjuangan.

Gambar 1. Skema ideologi islam radikal yang menjadi dasar dalam melancarkan propaganda $^{14}$

Setelah Al-Qaeda ditumpas habis oleh tentara Amerika dan para sekutu pada tahun 2000-an, gerakan radikal baru terbentuk yakni ISIS. ISIS adalah singkatan dari Islamic State of Iraq and Syria. Kelompok ingin membebaskan diri dari pemerintah dengan cara mengkudeta, merampas pemerintahan yang ada di negara Iraq dan Suriah. ISIS dibentuk pada tahun 1999 oleh Abu Bakar al-Baghdādi ${ }^{15}$. ISIS dibawah pimpinan Abu Bakar al-Baghdādi, Islam menjadi lebih religius dan berogranisasi monolitik, eksklusif, dan satu syariat, yang selanjutnya mereka terusmenerus mengkafirkan dan memerangi umat Islam lainnya yang tidak sepaham dengan mereka ${ }^{16}$. ISIS telah meresahkan masyarakat dunia tidak hanya bagi umat Islam saja. Penumpasan habis kelompok ISIS telah memasuki babak akhir dimana markas-markas yang menjadi persembunyian mereka telah dibom oleh tentara Amerika, Rusia, dan para sekutu. Saat ini hanya tersisa sedikit dari titik lokasi persembunyian ISIS yang ada di Suriah. Deklarasi kemenangan tantara militant Iraq, Amerika, Rusia bersama sekutu telah dikumandangan beberapa tahun yang lalu karena telah memenangkan pertempuran melawan ISIS di Iraq.

Gerakan propaganda dan radikalisme yang telah terjadi tidak terlepas dari pemikiran yang kuat dari seorang Sayyid Qutb. Sayyid Qutb sering disebut sebagai penyebab merebaknya paham takfiri. Pemikirannya juga

dipandang berbeda oleh mayoritas umat sepanjang sejarah umat islam. Secara garis besar, pemikiran Sayyid Qutb ini mempengaruhi terbentuknya kelompok-kelompok radikal seperti Hizbut Tahrir, Al-Qaeda, Ihkwanul Muslimin, dan ISIS. Banyak negara telah melarang ideologi ekstrim tersebut agar tidak masuk dan menyebar di negara mereka.

14 Tim Forum Kajian Ilmiah Ma’had Aly Lirboyo, op.cit., hlm. 18.

15 Tim Forum Kajian Ilmiah Ma'had Aly Lirboyo, op.cit., hlm. 15.

${ }^{16} \mathrm{~J}$. A. Ali, Social Construction of Jihad and Human Dignity in the Language of ISIS, hlm. 59.

34 | لurnal Auladuna

Vol.DI. №.QZ2. April 2019 
Pemikiran Sayyid Qutb yang juga didukung oleh kelompok-kelompok radikal sebelum masanya, radikalisme dalam Islam memiliki skema yang terdiri dari 8 butir seperti ditampilkan pada gambar 1. Al-hakimiyyah menjadi pangkal sumber radikalisme. Skema ini meyakini kekuatan Allah secara penuh dan mutlak, sehingga perkara-perkara yang tidak haq harus dilarang. Al-hakimiyah menjadi dasar dalam mengkafirkan pemerintah dan aparat negara karena menghambat dan menghalangi propaganda mereka kepada umat muslim lainnya. Jahiliyyah al-'Alam memandang bahwa masyarakat saat ini masih mengalami fase jahiliyah, dimana segala perilaku keagamaan mereka dianggap keliru dan harus segera diluruskan. AlWara' wa Al-Baro' meyakini bahwa hanya kelompoknya saja yang wajib dibela dan dikasihani, bagi mereka yang berbeda ideologi harus dimusuhi dan diperangi karena dianggap menghalangi syiar Islam. Dar al-harb memandang bahwa seluruh dunia ini berada dalam kekufuran hebat, sehingga perlu diperangi untuk menjadikan kembali satu faham dengan mereka. Jihad fi Sabilillah yang dianggap menjadi jalan suci untuk berperang dan membela agama Allah, melenyapkan segala kemungkaran yang ada di bumi, yang pada akhirnya tujuan mereka adalah membentuk negara Islam, negara khilafah yang terendus sebagai cita-cita politik dan puncak dari segala perjuangan yang telah merek lakukan.

Begitu banyak proses dan pergerakan yang masif dari kelompok radikal ini. Oleh sebab itu, dalam konteks Indonesia, Pemerintah di bawah komando Badan Nasional Penanggulangan (BNPT) terorisme harus mampu mempelajari dari mulai ideologi, skema, dan alur propaganda agar dampak yang ditimbulkan tidak semakin mengacaukan NKRI.

\section{Faktor Munculnya Propaganda Khawarij di Zaman Milenial}

Munculnya propaganda khawarij yang telah bertransformasi menjadi beberapa kelompok ekstrimis dipengaruhi oleh dua faktor yakni, faktor sosial dan faktor agama. Faktor sosial adalah faktor yang berhubungan dengan kondisi sosial dan interaksi masyarakat di suatu tempat. Sedangkan faktor agama lebih kepada faktor yang berhubungan dengan doktrin-doktrin agama ${ }^{17}$.

a. Faktor Sosial

Faktor sosial adalah faktor yang terpisah dari hubungan agama dan ideologi. Beberapa penyebab sosial munculnya ideologi khawarij di zaman milenial/modern yakni psikologis seseorang yang buruk, gejolak politik, ekonomi yang tidak stabil, budaya maupun dari pendidikan. Banyak kita temukan pengikut gerakan radikal memiliki psikologi yang buruk dan tertutup. Aktualisasi diri yang kurang dan cenderung menutup diri dari khalayak umum. Mereka merasa tidak sependapat dan satu pemikiran dengan masyarakat pada umumnya, yang akhirnya memutuskan untuk mengurung diri dan berjihad dengan bergabung menjadi anggota kelompok radikal.

Gejolak politik juga menjadi faktor pemicu merebaknya paham radikal. Contoh nyata adalah terjadinya perang di negara-negara timur tengah. Gejolak politik dan ketidakpuasan rakyat terhadap pemerintah memicu kelompok radikal untuk masuk dan ikut serta dalam menggulingkan pemerintahan. Prinsipnya adalah jika negara itu hancur maka kekuasaan akan mudah untuk direbut dan penyebaran radikal akan berjalan masif jika penguasa di negara tersebut adalah berasal dari kelompok mereka. Fenomena Arab Spring juga berkaitan erat dengan propaganda kelompok ekstrim dan radikal yang telah melancarkan aksinya di Timur Tengah. Banyak dari negara dan pemerintahan hancur karena ulah dari kelompok radikal tersebut karena memicu ketegangan dan konflik internal negara maupun antar negara

${ }^{17}$ Ibid. hlm. 19

Vol.I. No.D2. April 2019 
arab. Permusuhan Arab, Iran, dan Yaman terkadang juga ditunggangi oleh kelompok ekstrimis yang ingin menghancurkan sistem pemerintahan dan penguasanya untuk menanamkam doktrin radikal dan mendirikan negara Islam. Maka sudah seharusnya untuk mempertahankan keutuhan sebuah negara, agar supaya negara tersebut solid, bersatu, dan tidak mudah dikacaukan oleh kelompok-kelompok radikal yang ingin menguasai.

Ketidakstabilan kondisi ekonomi terkadang membuat orang buta untuk bergabung ke dalam kelompok radikal. Contohnya seperti ISIS yang mengiming-imingi wanita dan uang dalam proses perekrutan anggota baru. Godaan berupa wanita dan uang akan banyak menyedot perhatian kaum labil untuk masuk dan bergabung dengan gerakan radikal ini. Negarapun juga harus memiliki ekonomi yang kuat agar warganya dapat hidup sejahtera dan tidak mudah tergoncang oleh godaan kaum-kaum ekstrimis yang menjanjikan uang dan wanita. Membentengi diri dengan prinsip ekonomi yang baik, dipandang perlu untuk mencegah hal-hal yang tidak diinginkan terjadi.

Rasa fanatisme terhadap sesuatu yang berlebihna tentu membuat seseorang lupa terhadap kondisi sosial disekelilingnya. Fanatisme kesukuan yang muncul di masa kekhalifahan Ustman bin Affan R.A. membuat ketegangan antar suku di arab pada waktu itu menjadi tinggi. Ustman yang mengangkat saudara-saudaranya untuk menduduki jabatanjabatan penting dalam masa kekhalifahan dituduh mebgadakan nepotisme, sehingga muncul hujjah dari kaum khawārij untuk meengadakan kudeta terhadapnya ${ }^{18}$.

Budaya di suatu tempat juga berpengaruh besar terhadap masuknya doktrin garis keras. Budaya-budaya masyarakat yang apatis dan sulit bersosialisasi menyebabkan pola interaksi antar masyarakat berkurang. Permasalahan yang timbul tidak dapat dimusyawarahkan secara bersama oleh seluruh anggota masyarakat. Selain itu, kesadaran untuk merawat budaya asli Indonesia yang kurang menyebabkan ideologi asing mudah masuk. Self-awareness penting untuk menangkal doktrin dan paham-paham radikal dari asing. Seperti istilah jawa berbunyi "jowo digowo, arab diruwat". Artinya bahwa merawat kearifan lokal dan budaya asli Indonesia akan menjaga keutuhan budaya asli Indonesia, ikut serta melestarikannya, dan dapat menangkis ideologi-ideologi ekstrim yang tidak sesuai dengan falsafah Pancasila dan kebhinnekaan.

Faktor pendidikan juga mempengaruhi pola penyebaran ideologi radikal yang mencebabkan munculnya propaganda khawarij. Pendidikan merupakan faktor penting dalam membentuk pribadi seseorang menjadi pemikir. Jika orang tersebut sembit dalam berargumen dan bernalar, maka dia dapat dengan mudah didoktrin oleh paham-paham radikal. Bahkan pada beberapa kasus di Indonesia telah terjadi kasus "cuci otak" yang mengajarkan paham radikal kepada "mahasiswa labil" yang tidak memiliki nalar kuat dan pendirian yang teguh. Pendiri Al-Qaeda, Usāmah bin Ladin menjadi radikal karena menerima pemahaman yang radikal saat menempuh perkuliahan. Usāmah bin Ladin menerima pendidikan dari dosennya yang bernama 'Abdullah 'Azzām yang merupakan perintis Al-Qaeda di masa lalu. 'Abdullah 'Azzām pernah dikeluarkan dari jabatan dosen di Universitas Al-Azhar Mesir karena memiliki pemikiran yang radikal. Usāmah bin Ladin pun dapat dia doktrin untuk menghabiskan jutaan dollar untuk membiayai terorisme global ${ }^{19}$.

b. Faktor Agama

Selain faktor sosial, faktor agama juga menjadi faktor besar dalam pembentukan pribadi seseorang menjadi radikal. Dalam keadaan seperti ini, salah besar jika menisbatkannya

${ }^{18}$ Rubini, Khawarij dan Murji'ah Perspektif Ilmu Kalam, Jurnal Komunikasi dan Pendidikan Islam, 7(1), 2018, hlm. 98.

${ }^{19}$ Tim Forum Kajian Ilmiah Ma'had Aly Lirboyo, op.cit., hlm. 22. 
kepada Islam, karena kesalahan yang sebenarnya adalah kemampuan dan kapasitas keilmuan seseorang yang tidak mendalam serta ketidaksungguhan dalam menerima dan mengamalkan ajaran Islam. Kesalahan persepsi global yang menyandarkan seluruh propaganda yang terjadi karena Islam perlu diluruskan dengan segala daya upaya yang maksimal, termasuk diplomasi pemerintah terhadap negara-negara barat. Hal tersebut dikarenakan Islam sejatinya adalah agama yang membawa keselamatan bagi manusia, membawa perdamaian, saling menghargai, dan menjunjung tinggi keberagaman.

Seseorang yang cenderung memiliki paham agama yang minim bahkan hanya diperoleh dari internet, akan mudah diprovokasi dan didoktrin untuk bergabung ke dalam kelompok ekstrimis. Reduksi pemahaman keagamaan seseorang menyebabkan ketidakutuhan, tidak komprehensif, dan terputusnya sanad keilmuan saat mempelajari Islam dari cara yang instan. Kontekstualitas berupa pemahaman dari tulisan membuat mereka hanya menjadi kaum pemikir, pendebat, pen-takfir, tanpa adanya musyawarah, diskusi, dan pemikiran yang mendalam. Beberapa contoh tidak konsistennya dalam mempelajari agama islam antara lain suka mengambil satu teks/dalil namun mengabaikan dalil yang lainnya. Seolah-olah ayat/dalil yang mereka pegang itulah yang haq dan paling benar. Padahal kita semua hidup di era dimana nabi dan syuhada telah meninggal. Post-prophet era memiliki kecenderungan logis untuk memudahkan paham radikal masuk kedalam pemikiran masyarakat awam. Hal ini akan terus terjadi jika tidak dikuatkan dengan pemahaman aqidah dan pemikiran yang kuat tentang agama Islam. Lebih lanjut, para kaum ekstrimis sering menggunakan haditshadits doif dan hadits yang isinya tegas dan keras terhadap umat Islam. Mayoritas hadits yang digunakan adalah hasil riwayat Ibnu Taymiyyah. Ibnu Taymiyyah dianggap sebagai figur fundamental dari pergerakan ekstrimis di masa kontemporer ${ }^{20}$. Selain itu, para kaum ekstrimis ini juga suka menggunakan ayat yang terpenggal untuk menyerang kelompok lain, artinya tidak menyeluruh, sehingga menyebabkan terputusnya pemahaman dari suatu ayat/dalil.

Selain kekeliruan mereka dalam memahami teks, kesalahan selanjutnya adalah ketidaktepatan dalam menerapkan sebuah ayat/dalil dalam kehidupan bermasyarakat. Sebuah teks maupun produk hukum tidak serta merta dapat diterapkan kepada semua orang dan dalam segala kondisi. Islam mengatur keseluruhan kegiatan manusia tanpa satupun yang tertinggal. K.H. Ali Maksum, seorang ulama besar di Yogyakarta pernah berkata "dalil iki enek dalil wedok, enek dalil lanang, ora iso diwolak-walik". Artinya bahwa setiap ayat/dalil memiliki tupoksi dan fungsi yang berbeda-beda. Setiap dalil ada yang diperuntukkan kepada laki-laki dan ada juga dalil yang memang khusus untuk kaum perempuan. Semua tidak boleh dicampur bahkan dibolak-balik.

Pemahaman tertutup seseorang akan agama Islam juga menjadi penyebab doktrin radikalisme dapat berkembangan dengan mudah. Memahami teks keagamaan dan realita secara tertutup tidak dapat dielakkan bahwa menjadi salah satu penyebab radikalisme beragama berkembang. Pemikrian tertutup inilah yang mendasari tindakan-tindakan radikal yang telah dilakukan. Semangat yang menggebu-gebu dalam mempelajari Islam tanpa didasari dengan keluasan pikiran dan kebesaran hati hanya akan membuat seseorang masuk terjerumus ke jalan yang salah. Pemahaman tertutup juga dapat mempengaruhi pandangan kelompok radikal yang anti terhadap apapun yang tidak berdasarkan Alquran dan Hadits. Kelompok radikal juga sering menalar teks/ayat/dalil secara tekstual dengan cara diikutkan

${ }^{20}$ J.J. Kaminski, The Contemporary Islamic Governed State, Palgrave Series in Islamic Theology, law, and History, hlm. 58.

Vol.DI. No.DZ. April 2019 
pada nafsu mereka. Iniliha yang tentu di masa mendatang dapat menjadi bumerang bagi siapapun yang menganut paham radikal.

\section{Khawarij Zaman Milenial}

Kemajuan Ilmu Pengetahuan dan Teknologi ibarat dua mata pisau. Dampak positif tentu mempermudah generasi muda untuk mengakses informasi dari internet, namun dampak negatifnya juga banyak yang salah satunya menggunakan media sosial sebagai wadah untuk menghujat seseorang. Walaupun sudah dibentuk UU ITE oleh pemerintah dan DPR, namun dampaknya tidak terlalu signifikan serta belum memunculkan efek jera bagi pelaku pencaci dan penyebar ujaran kebencian di media sosial.

Khawārij zaman sekarang tidak jauh berbeda dengan khawārij zaman dahulu. Walaupun sampai hari ini kelompok khawārij sudah tidak ada, namun warisan mereka berupa faham radikal telah berkembangan menjadi kelompok-kelompok lain dan mempengaruhi pola pikir sebagian umat Islam. Hal tersebut dapat diamati terutama mereka yang belajar Islam hanya dari media sosial dan internet, tanpa memastikan sanad keilmuannya. Sebagian dari kelompok ini ada yang memahami alquran dengan baik dan taat beribadah. Namun, secara bathin mereka telah terpapar ekstrimisme, radikalisme, dan keyakinan-keyakinan yang merusak kerukunan umat Islam. Khawārij milenial lebih sering merasa benar dan kerap sekali menyalahkan yang lain. Mereka suka mencaki maki orang yang berbeda pandangan politik dan pemahaman Islam. Korbannyapun tidak hanya orang biasa, namun sudah mencakup tokoh-tokoh dan ulama besar di tanah air.

Contoh nyata adalah ketika K.H. Yahya Cholil Staquf yang merupakan Katib Aam Pengurus Besar Nahdlatul Ulama (PBNU) sekaligus sebagai pengasuh Pondok Pesantren Raudlatut Thalibin, Rembang, mendapat serangan habis-habisan di media sosial karena telah menghadiri seminar di Yerussalem. Padahal beliau menghadiri seminar tersebut untuk mengisinya dengan menebar gagasan Islam Rahmatan lil 'Alamin. Anehnya cacian, hujatan, dan tuduhan yang mereka lakukan dilandasi dengan semangat membela agama ${ }^{21}$. Kebuntuan berpikir seperti ini menyebabkan dangkalnya pemikiran generasi milenial untuk menelusuri secara jelas tentang penyebab sebuah peristiwa. Justifikasi yang tidak berdasar hanya akan menjerumuskan mereka ke dalam kesesatan berpikir. Beberapa contoh lain seperti tuduhan kafir terhadap cak nun, dan syiah terhadap K.H. Qurais Shihab adalah ulah para remaja yang masuk kedalam kategori khawārij milenial. Pada gambar 2, ditampilkan screenshot salah satu media online nasional yang mengabarkan tentang kecaman dan pembelaan kepada K.H. Yahya Cholil Staquf.

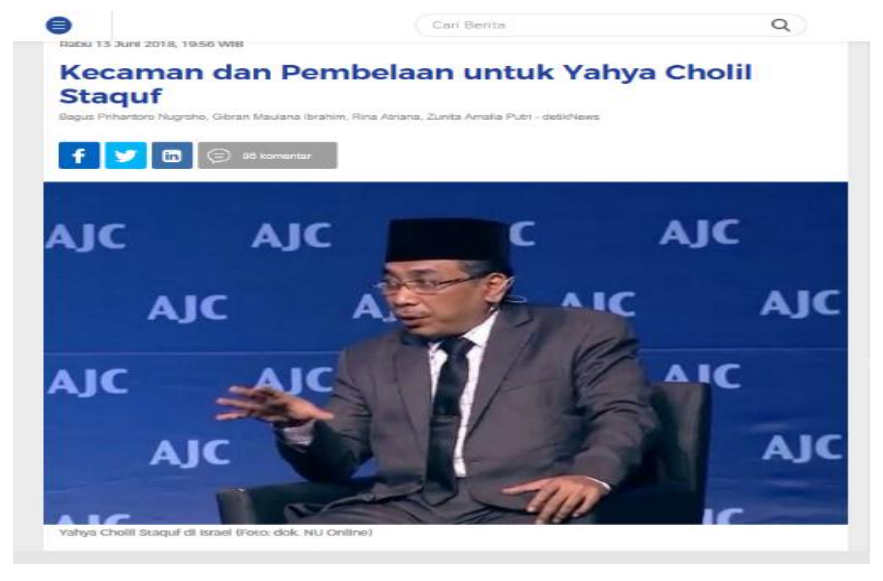

${ }^{21}$ Sarjoko, Mencegah Khawarij Milenial di Sekitar Kita. 
Gambar 2. Screenshot berita tentang K.H. Yahya Cholil Staquf ${ }^{22}$

Analisis konten terhadap kaum khawārij yang sering berinteraksi di media sosial dapat dilacak dengan mengakses website https://keyhole.co. Pada analisis konten yang telah dilakukan, dua kata kunci yakni "khawārij" dan "kafir", digunakan. Kedua kata kunci tersebut dipilih karena erat hubungannya dengan propaganda khawārij milenial meskipun seluruhnya tidak mencerminkan upaya propaganda yang akan dilakukan. Berikut ditampilkan ulasan dari kata kunci "khāwarij" di media sosial maupun blog.



Gambar 3. Real-time tracker kata "khawārij" di internet ${ }^{23}$

Gambar 3 menunjukkan bahwa pada rentang waktu 21-28 februari 2019 telah terjadi 410 postingan, 323 pengguna, 1.193 keterlibatan akun, 320.961 jangkauan, dan mempengaruhi munculnya 372.971 percakapan tentang kata "khawārij". Postingan, interaksi, dan percakapan di media sosial mengenai kata kunci "khawārij" sering terjadi di saat-saat pemilu, kasus-kasus yang trending, serta pada topik-topik headline media massa. Hal tersbeut wajar terjadi mengingat setiap ada berita yang trending, masyarakat dunia maya (netizen) banyak merespon dengan berbagai postingan dan cuitan di twitter. Ada yang merespon postif, negatif, dan banyak juga yang abstain (netral).

Selain menganalisis berdasarkan jumlah postingan di media sosial, sentimentasi (perasaan) pengguna internet juga dapat dianalisis menggunakan website https://keyhole.co. Sentimentasi pengguna internet tentang kata "khawārij" mayoritas memiliki eskpresi negatif seperti benci dan marah, sedangkan yang lainnya netral (yang ditunjukkan dnegan warna biru). Warna hijau menunjukkan ekspresi positif yang jumlahnya sangat sedikit. Untuk lebih jelasnya, dapat melihat gambar 4 sebagai berikut.

\footnotetext{
${ }^{22}$ Detik, https://news.detik.com/berita/d-4067709/kecaman-dan-pembelaan-untuk-yahya-cholil-staquf

${ }^{23}$ https://keyhole.co/hashtag-tracking/dashboard/BHRA6K/Khawarii?days=7

Vol.미. No.D2. April 2019 


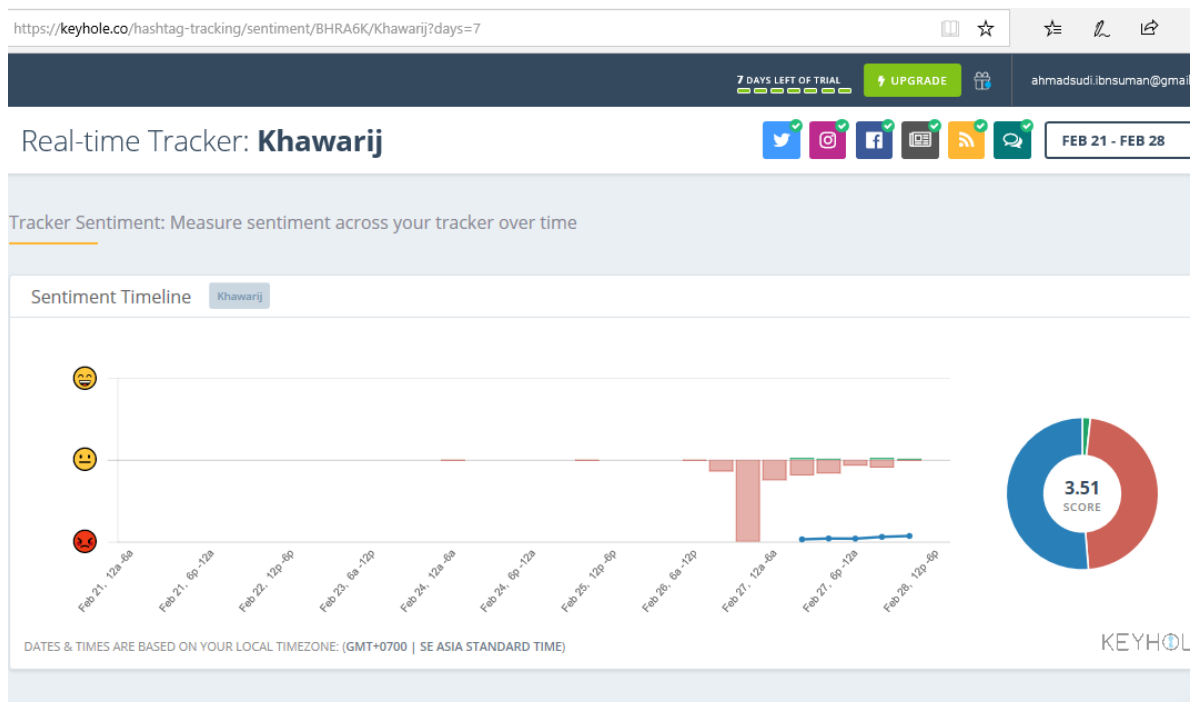

Gambar 4. Sentiment timeline kata "khawārij" di internet ${ }^{24}$

Hal tersebut mencerminkan bahwa memang sejatinya ekspresi netizen mengenai kata khawarij sendiri memiliki sentimen negatif. Mereka secara perlahan mulai menyadari bahwa postingan hoax, hujatan, menyerang yang ditandai dengan hashtag \#khawārij berakhir dengan hal-hal yang negatif. Bahkan beberapa waktu lalu, media sosial seperti twitter dan facebook sering memblokir dan menghapus akun-akun yang dinilai radikal dan sering menyebarkan fitnah, hoax, serta propaganda perang dan kejahatan.

Kata kunci kedua yang digunakan adalah kata "kafir". Kata tersebut digunakan untuk mendeteksi penggunaan kata tersebut di internet dan sentimen (ekspresi) netizen terhadap kata tersebut. Hasilnya akan ditampilkan seperti pada gambar 5 berikut.

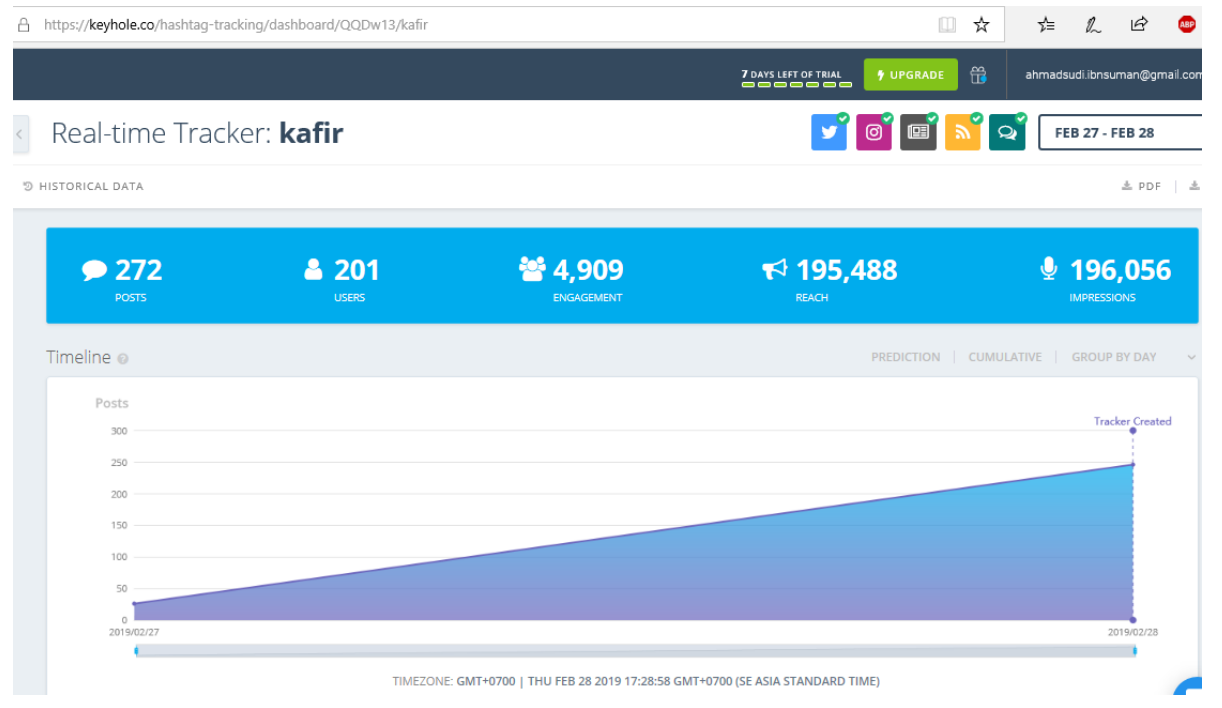

${ }^{24}$ Ibid.

40 | Jurnal Auladuna

Vol.DI. No.G2. April 2019 
Gambar 5. Real-time tracker kata "khawārij" di internet ${ }^{25}$

Gambar 5 menunjukkan bahwa hanya pada rentang waktu 27-28 februari 2019 telah terjadi 272 postingan, 201 pengguna, 4.909 keterlibatan akun, 195.488 jangkauan, dan mempengaruhi munculnya 196.056 percakapan tentang kata "kafir". Hal tersebut ternyata lebih tinggi jika dibandingkand engan analisis konten terhadap kata "khawārij". Artinya pengguna internet lebih sering menggunakan kata "kafir" daripada kata "khawarij" dalam berargumen, berdiskusi maupun kegiatan menghujat, mengkritik, dan men-takfir-kan orang lain. Sedangkan untuk sentimentasi pengguna internet tentang kata "kafir" terlihat bahwa pada tanggal 27-28 Februari 2019 sentiment timeline menunjukkan mayoritas memiliki ekspresi negatif. Hal tersebut ditunjukkan dengan warna merah pada gambar 6 sebagai berikut.

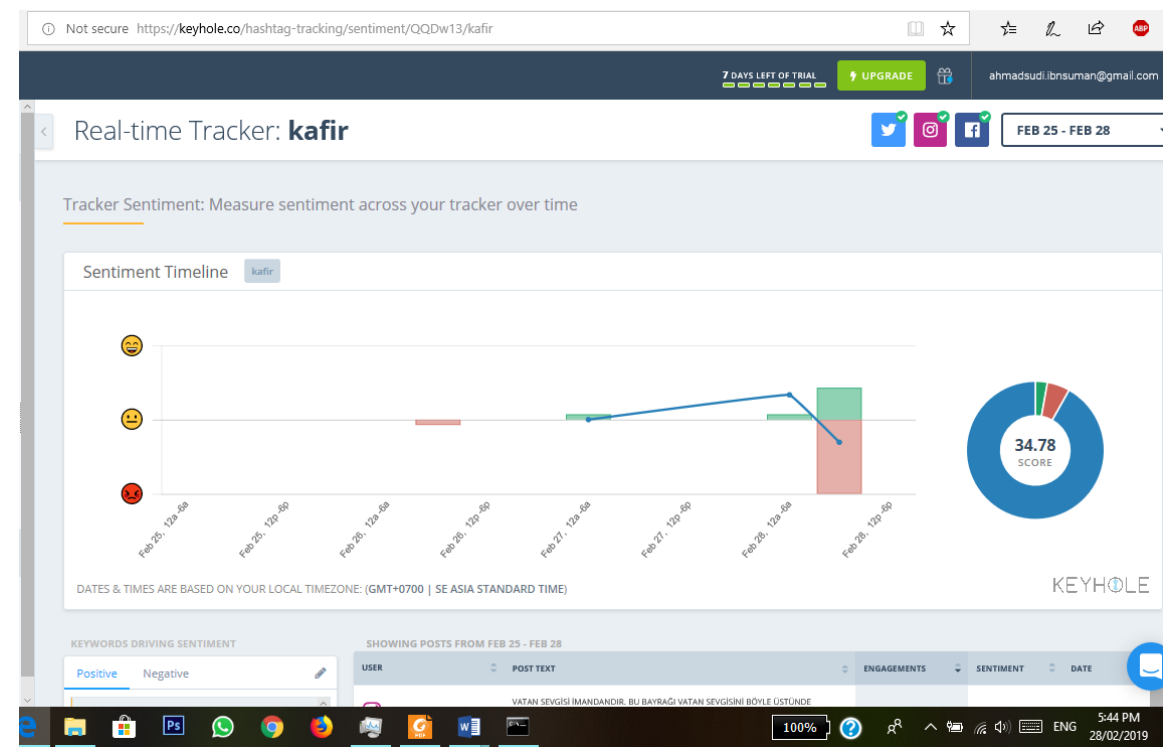

Gambar 6. Sentiment tracker kata "kafir" di internet ${ }^{26}$

Berdasarkan beberapa tampilan screenshot tersebut, dapat disimpulkan bahwa untuk menelusuri perilaku netizen mengenai propaganda dari kaum khawārij milenial memang sulit dilakukan, karena akun-akun yang menyebarkan propaganda tersebut cenderung anonim dan sulit untuk dideteksi. Namun, setidaknya dengan menelusuri dua kata kunci tersebut menggunakan fasilitas TweetTracker, dapat diambil asumsi awal bahwa propaganda kaum khawarij milenial masih tetap berjalan dan terjadi hingga detik ini. Pemerintah harus mengambil sikap preventif dan antisipatif agar propaganda di jagat maya tidak semakin luas.

Indonesia mengalami bonus demografi dimana sebagian besar penduduknya adalah remaja berusia produktif antara 18-30 tahun. Para remaja ini harus benar-benar dibina dan dibimbing agar tidak mudah mencaci-maki, menghujat orang lain serta dapat lebih bijak dalam menggunakan internet dan media sosial dalam berkomunikasi. Peran guru tentu menjadi salah satu peran sentral dimana figur seorang guru, pengajaran seorang guru harus mampu memberikan keteladanan yang mampu ditiru oleh murid-muridnya untuk berperilaku seharihari dengan baik. Orangtua dalam keluarga, sebagai gerbang awal anak dalam memperoleh

${ }^{25}$ Ibid.

${ }^{26}$ Ibid.

Vol.DI. No.QZ2. April 2019 
informasi harus memberikan filtering secara ketat dan berkesinambungan. Hal tersebut dilakukan untuk meminimalisir pergerakan kaum khawarij modern melakukan propaganda, penanaman doktrin radikal terhadap anak-anak mereka. Apalagi jika di kampus-kampus masih ditemukan organisasi ekstrimis dan radikal seperti HTI.

\section{Kesimpulan}

Kaum khawārij telah bertransformasi menjadi kelompok-kelompok radikal baru yang banyak berada di berbagai negara di dunia. Tidak hanya serangan fisik yang mereka gencarkan, bahkan internet juga tidak luput untuk dijadikan sebagai media propaganda pemikrian radikal yang mereka anut, tentu dengan tujuan untuk mendoktrin para pengguna media sosial untuk berperilaku radikal dan ekstrim. Sewajarnya dan penting sekali bagi para guru dan orangtua untuk dapat mengawasi anak mereka agar tidak terpapar radikalisme dan doktrin ekstrim, mengingat kedua hal tersbeut dapat menimbulkan bahaya bagi keluarga, bangsa, dan agama, serta keutuhan Negara Kesatuan Republik Indonesia.

\section{Daftar Pustaka}

Kharijis/Kharijities, The Oxford Dictionary of Islam, http://www.oxfordislamicstudies.com/article/opr/t125/e1274, diakses 298 Februari 2019.

al-Asqalānī, Ibnu Hajar Ahmad ibn 'Ali, Hadyu al-Sari: Muqaddimah Fath Bāri, Beirut: Dar alMa'rifah, - .

Ali, J. A., Social Construction of Jihad and Human Dignity in the Language of ISIS, Chapter 4. Middle East Today, https://doi.org/10.1007/978-3-030-02719-3 4, 2019.

al-Nawawi, Muḥyi al-Dīn Yahya ibn Sharaf, Sharhu al-Nawāwi 'alà Sahịh Muslim, Beirut: Dār Ihya al-Turāts, 1392.

al-Shahrastāni, Muhammad ibn 'Abdu al-Karim, al-Milāl wa al-Nị̣äl, Beirut: Dar al-Ma'rifah, 2000.

Analisis kata "khawarij", https://keyhole.co/hashtagtracking/dashboard/BHRA6K/Khawarij?days=7, diakses 28 Februari 2019.

Detik, Kecaman dan pembelaan untuk yahya cholil staquf, https://news.detik.com/berita/d4067709/kecaman-dan-pembelaan-untuk-yahya-cholil-staquf, diakses 28 Februari 2019.

Kaminski, J. J., Trajectory of the Development of Islamic Thought-A Comparison Between Two Earlier and Two Later Scholars, Chapter 2. Palgrave Series in Islamic Theology, Law, and History, https://doi.org/10.1007/978-3-319-57012-9 2, 2017.

NU Online, Berkatalah yang Baik atau Diam Saja, www.nu.or.id/post/read/72224/berkatalahyang-baik-atau-diam-saja, 2016.

NU Online, Ibnu Muljam Membunuh Ali karena Hoaks http://www.nu.or.id/ post/read/91475/ibnu-muljam-membunuh-ali-karena-berita-hoaks, 2016.

Rubini., Khawarij dan Murji'ah Perspektif Ilmu Kalam, Jurnal Komunikasi dan Pendidikan Islam, 7(1), 2018.

Said Ali, As'ad., Al-Qaeda: Tinjauan Sosial-Politik, Ideologi dan Sepak Terjangnya, Jakarta: LP3ES, 2014.

42 | Jurnal Auladuna

Vol.DI. №.QZ2. April 2019 
Sarjoko, Mencegah Khawarij Milenial di Sekitar Kita, dalam https://islami.co/mencegahkhawarij-milenial-di-sekitar-kita/, diakses 26 Februari 2019.

Sukring., Ideologi, Keyakinan, Doktrin dan Bid'ah Khawarij: Kajian Teologi Khawarij Zaman Modern. Jurnal Theologia, 27(2), 2016

Tim Forum Kajian Ilmiah Ma'had Aly Lirboyo. Kritik Ideologi Radikal, Kediri: Lirboyo Press, 2018.

Wahid, Abdurrahman. dkk., Ilusi Negara Islam, Jakarta: The Wahid Institute, 2009.

Williams, J. A., Corfield, J., DeLong-Bas, N. J., The Oxford Encyclopedia of Islam and Women, http://www.oxfordislamicstudies.com/article/opr/t355/e0150? hi=0\& pos=4, diakses 28 Februari 2019.

Williams, J. A., dan Korfield, J., Kawārij, http://www.oxfordislamicstudies.com/article/opr/t236/e0450? hi=0\& pos=2, diakses 28 Februari 2019.

Zubaidah, S., dan M., Zulkifli, Doctrine and thought of khawarij and the implication in the present context, International Journal of Applied Engineering research, Vol. 11(6), 2016. 